\section{Milli Eğitim Şuralarında Eğitim ve Okul Yöneticiliği}

Tuğçe Bulut Boz ${ }^{1}$ İbrahim Hakan Karataş ${ }^{2}$

Özet

Okul yöneticiliğinin bir uzmanlık alanı olarak tanımlanmasına ilişkin tartışmaların, 2023 Eğitim Vizyonu’nda yer verilen ilgili hedeflerle yeniden gündeme geldiği görülmektedir. Yasalaşması düşünülen ögretmenlik meslek kanunu kapsamında okul yöneticiliğinin meslek tanımının ve kariyer evrelerinin belirlenmesi beklenmektedir. Türkiye'de okul yöneticiliğine ilişkin tartışmaların tarihi gelişiminde MEŞ’lerde alınan kararlar önemli bir yer tutmaktadır. MEB tarafından 2-6 Aralık 2014 tarihleri arasında düzenlenen 19. ve son MEŞ in ana gündem maddelerinden biri de "Eğitim Yöneticilerinin Niteliğinin Artırılması” olarak belirlenmişti. Bu çalışmada 19. MEŞ da dahil olmak üzere 1981'den bu yana yapılan şuralarda okul yöneticiliği ile ilgili tartış̧lan konular ve alınan

Anahtar kelimeler: Okul yöneticiliği, Milli eğitim şuraları, Uzmanlık mesleği, Eğitim yönetimi.

\section{An Analysis of the Decisions Taken in the National Education Councils on Educational and School Administration}

\section{Abstract}

The arguments on defining school administration as a field of specialization came back on the agenda with the main objectives given in Turkey's "2023 Education Vision." Within the scope of the teaching profession law, it is expected to determine the job description and career stages of school administrators clearly. The decisions taken by the National Education Council have an important role in the history of the development of the arguments regarding school administration in Turkey. One of the main agenda items of the 19th nd last National Education Council organized by the Ministry of National Education between 2-6 December 2014 was "Increasing the Quality of Educational Administrators". In this study, the issues argued and the decisions taken in councils which were held since 1981, including the 19th National Education Council, were compiled and analyzed.

Keywords: School administration, National Education Council, Specialization job, Educational administration. kararlar derlenmiş ve analiz edilmiştir.

http://dx.doi.org/10.22596/ cresjournal.0102.108.130

\section{Derleme}

\section{Review}

Başvuru/Submitted

15 Ara/Dec 2020

Kabul/Accepted

28 Ara/Dec 2020

Yayın/Published

29 Ara/Dec 2020

ISSN

2718-0808

1 MEB müdür yrd, tugcebulut89@gmail.com, ORCiD: 0000-0002-4281-9423

Eğitim: 2012 yılında, Kocaeli Üniversitesi İngiliz Dili ve Edebiyatı bölümünde lisans eğitimini tamamladı. Halen, İstanbul Medeniyet Üniversitesi Eğitim Kurumları İşletmeciliği programında yüksek lisans eğitimine devam etmektedir.

2 Doç. Dr. İstanbul Medeniyet Üniversitesi, ihkaratas@gmail.com, ORCID:0000-0001-5569-014X

Eğitim: Boğaziçi Üniversitesi Türk Dili ve Edebiyatı Bölümünde 1998'te lisans, 2001'de yüksek lisans eğitimini tamamladı. 2008'de Marmara Üniversitesi Eğitim Yönetimi Teftişi Planlaması ve Ekonomisi ABD'de doktora eğitimini tamamladı. 


\section{Giriş}

Toplumların şekillenmesinde önemli bir yeri olan eğitim sistemi, bireylerin sahip oldukları yeteneklerini fark etmesinde etkili bir role sahiptir. Bu noktada, Mili

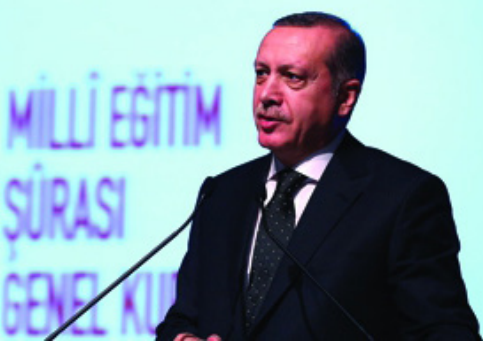
Eğitim Bakanlığının (MEB) aldığı her karar milyonlarca öğrencinin hayatını etkilemektedir. MEB'in en yüksek danışma kurulu olarak Cumhuriyet tarihi boyunca hizmet veren Milli Eğitim Şurası (MEŞ) eğitimin niteliğini arttırıcı önerilerde bulunmak ile yükümlüydü (MEB, 2014). Milli Eğitim Şuraları, 2 Temmuz 2018 tarihli 703 nolu KHK’nın 22. Maddesi ile lağvedilmiş ve böylece Cumhuriyet tarihinin eğitim alanında kurumsallaşmış tartışma ve karar alma mekanizması kaldırılmıştır (Cumhurbaşkanlığı, 2018)

Kelime anlamı olarak "bir alanla ilgili olarak oluşturulan danışma kurulu” şeklinde belirtilen (TDK, 2020) Şûra kelimesi Osmanlı Devleti’nde de önemli bir yere sahipti. Danıştay anlamında kullanılan Şûrayı Devlet kurumunun devlet yönetiminde en etkili olan kurumlardandı (TED, 2014). Milli eğitim bakanının da doğal üyesi olduğu MEŞ’lerde kararlar üyelerin oy çokluğuna göre alınmaktaydı. MEŞ’te doğal üye ve davetli üye olmak üzere iki tip üye bulunurdu. Tabii üyeler; “TBMM Milli Eğitim, Kültür, Gençlik ve Spor Komisyonu Başkanı ve üyeleri, milli eğitim bakanı yardımcısı, müsteşar ve bakanlık merkez teşkilatı birim amirleridir” (MEB, 2014). Davetli üyeler ile ilgili ise MEŞ Yönetmeliği'nde; "Bakanlık, bakanlıklar, kamu kurum ve kuruluşları, yerel yönetimler, üniversiteler ile yurt içinden ve yurt dışından meslek odaları, sivil toplum kuruluşları, özel sektör, basın ve yayın kuruluşları, öğrenci ve veli temsilcileri ile eğitim alanında Şura konusu ile ilgili çalışmaları ile tanınmış uzmanlar arasından Genel Sekreterlikçe belirlenerek Bakanlık onayına sunulur” şeklinde bir ibare yer almaktaydı (MEB, 2014).

İlki 1939 yılında olmak üzere şimdiye kadar toplamda $19 \mathrm{MEŞ}$ toplanmıştır. Şûralarda, eğitim yöneticiliği, okul yöneticiliği ve eğitim uzmanlığı

Illki 1939 yılında olmak üzere şimdiye kadar toplamda 19 MEŞ toplanmıştır. Şûralarda, eğitim yöneticiliği, okul yöneticiliği ve eğitim uzmanlığı gibi birçok konuda karar alınmıştır. MEŞ'te alınan kararlar tavsiye niteliği taşıdığı için kararların bir kısmı uygulanmıştır. 
gibi birçok konuda karar alınmıştır. MEŞ’te alınan kararlar tavsiye niteliği taşıdığı için kararların bir kısmı uygulanmıştır. Bu çalışmada MEŞ’lerde eğitim ve okul yönetimi kapsamında alınan kararların uygulanma düzeyleri incelenecektir.

Eğitim yönetimi eğitim kurumlarının daha verimli hale dönüşmesine ve tüm paydaşlara sahip oldukları beşerî ve fiziksel kaynakları en etkili şekilde kullanabilme yetkinliğini kazandırmayı amaçlamaktadır. Eğitim kurumlarının amaçlarına ulaşabilmesi için tıpkı diğer tüm örgütlerde olduğu gibi eğitim örgütleri de sahip oldukları beşerî gücü, zaman, sermaye ve malzemeyi en etkili şekilde kullanmalıdır. İyi bir örgüt yapısı için ortak amaç, maddi imkanlar, iş bölümü ve uzmanlaşma, görev tanımı, yetki ve sorumluluğun eşitliği, komuta ve yönetim birliği gibi birçok unsur gerekmektedir (Ürey ve Yılmaz, 2015: 147). Ancak, her örgütte olduğu gibi eğitim kurumlarında da gerek kaynakları kullanabilecek gerekse sahip olduğu kaynakları ortak bir amaç doğrultusunda yönetebilecek yeterliliğe sahip yöneticilere ve etkili denetim mekanizmalarına ihtiyaç vardır. Ancak 10. MEŞ’e kadar eğitim ve okul yöneticiliği ile ilgili bir maddeye yer verilmemiştir.

MEŞ’lerde eğitim ve okul yönetimi ile ilgili ne tür kararlar alınmıştır? Bu soruya ilişkin analizlere geçmeden önce bu konuda yapılan bazı çalışmaların sonuçlarını özetlemek yararlı olacaktır. Şûra kararları birçok bilimsel çalışmada incelenmiştir. Şûraları belli konular bakımından (Duman, 1988; Aydın, 1998), dönemsellik bakımından (Bayrak, Himmetoğlu ve Ayduğ, 2020), eğitim politikalarına etkileri bakımından (Eriş, 2006; Üçler, 2006; Serçin, 2009; Çakır, 2017; Gülşen ve Özkan, 2016; Öz, 2019) ele alan çalışmalar yapılmıştır. Bu çalışmanın konusu olan eğitim ve okul yöneticiliği bakımından Şûraları inceleyen araştırmacılardan biri olan Öz (2019) şûralarda okul yöneticilerinin yetiştirilmesi ile ilgili kararlara vurgu yapmakla beraber her okul düzeyinde bir “Okul Gelişim Yönetim Ekibi (OGYE)” kurulmasını ve söz konusu ekibin okul yöneticisi olmak isteyen öğretmenlerin öğrenme çevikliği ve potansiyellerini belirleyip il ve ilçe milli eğitim müdürlüklülerine bildirmek ile yükümlü olması gerektiğini belirtmiştir. Araştırmacı bu şekilde oluşacak yönetici havuzundan yöneticilerin seçilebileceğini önermektedir.

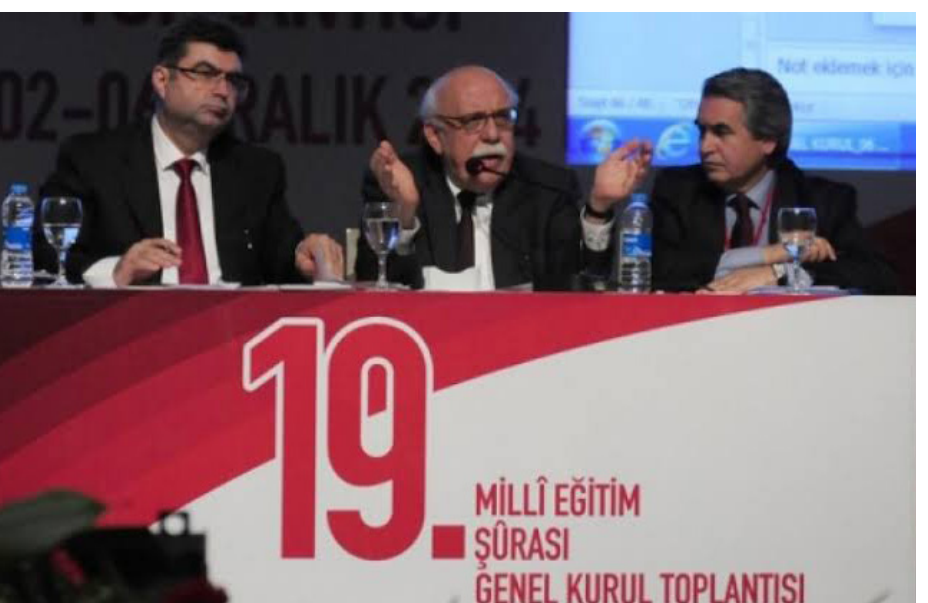

Duman

eğitim sistemindeki uzmanlık sorununa değinmiştir.

Araştırmac1, Milli Eğitim Gençlik ve Spor Bakanlığı ile eğitim uzmanı ve uzman yardımcısı yetiştiren kurumların sürekli iletişimde olması gerektiğini belirtmiş 
ve 11. MEŞ’te eğitim uzmanları ile ilgili alınan kararları yorumlamıştır. Son olarak, uzman niteliklerinin arttırılması yönünde uyarılarda bulunmuştur.

Aydın (1998) ise çalışmasında MEŞ’lerde alınan kararların bilimsellik ve demokratiklik niteliklerini tartışmıştır. Öğretmen, öğrenci ve velilerin yeterince temsil edilmediği ve tavsiye niteliğinde de olsa alınan kararların bu yönü ile bilimsel nitelik taşımadığı belirtilmektedir. Çalışma içerisinde MEŞ’lerin eğitim sorunlarına çözüm getiremediği ve eğitim sistemine yön veremediği de ayrıca belirtilmiştir.

1961-1987 yılları arasındaki MEŞ’ler ve alınan kararların ne derecede uygulandığına ilişkin çalışma ise Eriş (2006) tarafından gerçekleştirilmiştir. Bir yüksek lisans tezi olarak hazırlanan çalışmada MEŞ’lerde alınan kararların büyük ölçüde uygulanmadığı belirtilmiştir. Bu kapsamda 7. Şurada ilköğretim ile ilgili alınan kararların kısmen uygulandığı ancak 8. MEŞ’te alınan kararların uygulanmadığı belirtilmiştir. Bu dönemde uygulanabilirlik seviyesi en yüksek olan şura 11. MEŞ’tir. Eriş (2006) toplumların gelişmesinde eğitimin önemini vurgulayarak geçmiş şuralarda değinilen bazı sorunların günümüzde de geçerliliğini koruduğunun altını çizmiştir.

Eriş (2006)'in çalışmasının devamı niteliğinde olan ve 1988-2005 yılları arasında gerçekleştirilen MEŞ’leri inceleyen Üçler (2006) de kararların büyük ölçüde tavsiye niteliğinde kaldığını belirtmiş ve bu durumun MEŞ’in bir danışma kurulu niteliğinde görev yapması ve kararların uygulanmasının dönemin hükümetinin bakış açısı ile ilgili olduğunun altını çizmiştir.

Çakır (2017) bugüne kadar yapılan şûralarda öğretmen haklarından, hizmet içi eğitime kadar birçok konunun gündeme geldiğini ve MEŞ’lerin eğitim sistemindeki problemlere yanıt verebilecek nitelikle öneriler sunduğunu ancak önerilerin büyük bir kısmının uygulamaya geçirilmediği bu nedenle sadece tavsiye niteliğinde kaldığını belirtmiştir. Bu noktada, öğretmen ve bakanlık bünyesindeki üst düzey bürokratların Şûralara katılımının sağlanması toplantılar sırasında alınan kararların daha kolay uygulanabilir hale gelebileceğini eklemiştir. Bu noktada, Gülşen ve Özkan (2016) da Şûralarda alınan birçok kararın uygulamaya konulmadığını ve 1. MEŞ ile 19. MEŞ arasında farklılıkların yanı sıra benzerliklerin de olduğunu belirtmiştir. $\mathrm{Bu}$ bağlamda her iki çalışma da benzer bir soruna dikkat çekmiştir.

Serçin (2019) tarafından gerçekleştirilen ve 2008-2018 yılları arasında yapılan MEŞ’lerde eğitim yönetimi ve denetimi ile ilgili alınan kararları ve kararların uygulanabilirlik derecesinin incelendiği çalışmada ise eğitim yönetimi ile ilgili alınan kararların büyük bir kısmının yönetici atamaları ile ilgili olduğun vurgulamıştır. Araştırmacı, MEŞ kararları içerisinde yönetici görevlendirmede lisansüstü eğitim şartı ve başöğretmen ve uzman öğretmen ile ilgili olanların henüz uygulamaya konulmadığını da eklemiştir. 
Bayrak ve diğerleri (2020) tarafından gerçekleştirilen araştırma sonuçlarına göre yöneticilerin büyük bir bölümü okul yöneticiliğinde mülakat uygulamalarının nesnellikten uzak olduğunu düşünmektedir. Bu kapsamda, okul yöneticileri 19. MEŞ’te okul yöneticisi atamalarına ilişkin sunulan önerilerde liyakatin ön planda olduğunu belirtmiştir. Çalışma sonucunda yöneticilik öncesi lisansüstü eğitim uygulamaları ve okul müdürlüğü için öncesinde müdür yardımcıllı̆ı yapmış olma şartı da katılımcılar tarafından desteklenmiştir. 19. MEŞ’te önerilen okul karnesi konusu ile ilgili katılımcılar bölgesel farklılıkların dikkate alınmayacağı konusunda endişelerini dile getirmiştir.

Görüldüğü gibi tüm çalışmaların ortak noktası MEŞ kararlarının uygulanmaması ve kararlarının bazılarının kendilerini tekrar eden bir niteliğe bürünmesidir. Bu kapsamda, MEŞ toplantılarında öğretmen, öğrenci ve veli temsilcilerinin de fikirleri alınmalı ve kararlar daha uygulanabilir hale getirilmelidir. Bu konuda, MEB’in MEŞ kararlarını uygulama noktasında daha istikrarlı davranması beklenmektedir.

\section{Araştırmanın Yöntemi}

$\mathrm{Bu}$ çalışma belge inceleme yöntemiyle gerçekleştirilmiştir. Araştırma kapsamında ilki 1939 yılında sonuncusu ise 2014 yılında olmak üzere gerçekleştirilen 19 MEŞ’te alınan eğitim ve okul yöneticiliği ile ilgili olan kararlar değerlendirilmiştir. Bu kapsamda, MEŞ kararları ile ilgili birincil ve ikincil kaynaklar incelenmiş ve alınan kararlar yorumlanmıştır. Eğitim ve okul yöneticiliği ile ilgili alınan kararlar ve toplantının gerçekleştiği dönem Tablo 1'de gösterilmiştir.

\section{MEŞ’lerde Eğitim Yönetimine İlişkin Kararlar}

Bugüne kadar gerçekleştirilen on dokuz MEŞ’in hemen hepsinde şu ya da bu şekilde eğitim yönetimi ve organizasyonu gündeme gelmiştir. Ancak özellikle bazı şûralarda eğitim yönetimine ilişkin konuların ana gündem olarak belirlendiğini ve etraflıca tartışıldığı görülmektedir. Mesela 1981 yılında düzenlenen 10. MEŞ’te Türk Eğitim Sistemi’nin örgütlenmesi, 1982 yılında düzenlenen 11. MEŞ’te ise öğretmen ve eğitim uzmanlarının durum ve sorunları tartışılmıştır. 1988 yılındaki 12. MEŞ’in ana gündemi Türk Milli Eğitim Sistemi olmakla beraber eğitim yönetimine yer verilmediği görülmektedir. 1990'da gerçekleştirilen 13. MEŞ’te yaygın eğitim etraflıca tartışılırken 1993'te gerçekleştirilen 14. MEŞ eğitim yönetimi ve eğitim yöneticiliği gündemi ile toplanan ilk şûradır. 1996'da 15. MEŞ’te ise ortaöğretim yapılandırılması gündemi altında okul yöneticiliği konusunun etraflıca ele alındığı görülüyor. Ana gündemi mesleki eğitim olan ve 1999'da gerçekleştirilen 16. MEŞ’te mesleki eğitimde öğretmen ve yönetici yetiştirme konuları tartışılmıştır. 2006'daki 17. MEŞ’te ana gündem olarak teftiş sistemi tartışılmış olmasına rağmen yönetim kademelerine göre iş analizine dayalı "yönetici yeterlilikleri" 
saptanması gerektiği ilk kez karara bağlanmıştır. 2010'da gerçekleştirilen 18. MEŞ’te eğitim ve okul yöneticisinin yeterlilikleri, yetiştirilmesi, seçilmesi ve hizmetiçi eğitimi konusunun güncel bilimsel veriler ve kavramlar çerçevesinde geniş bir biçimde el alındığı görülmektedir. Son MEŞ olan 19. MEŞ’te okul yöneticilerinin niteliklerinin artırılması başlı̆̆ı altında okul yöneticiliği aday seçiminden görevdeki hak ve yetkilerine kadar bütün boyutlarıyla tartışıldığı ilk şûra olmuştur. Aşağıda eğitim yöneticiliği konusunda MEŞ’lerde alınan kararlar kısa analizlerle özetlenmiştir.

\section{MEŞ (23-26 Haziran 1981)}

Milli eğitim sistemimizin örgütlenme biçiminin tartışıldığı 10. MEŞ’te yönetici yeterliliklerinin artırılması için hizmet içi eğitimden geçirilmeleri gerektiği ve eğitim örgütünü daha ademimerkeziyetçi bir yapıya dönüştürecek düzenlemelerin yapılması gerektiği karara bağlanmıştır (TKB, 1981).

Aradan geçen 39 yıl boyunca milli eğitim sistemimizin merkeziyetçi örgütlenme biçiminde kısmı iyileştirmeler yapılmış ve bazı yetkiler taşraya devredilmiştir. En son 2011'deki MEB teşkilat yapısı ile ilgili 652 sayılı kanun hükmünde kararname ile merkezi teşkilat yapısı küçültülmüş ve merkez ve taşra teşkilatı yöneticilerinin yeterlik, görev, yetki ve sorumlulukları yeniden düzenlenmiştir. Mart 2014'te bazı kanunlarda yapılan değişiklikler ile de eğitim ve okul yöneticiliğine ilişkin düzenlemeler yapılmıştır.

\section{1. $M E S$ (8-11 Haziran 1982)}

Eğitim ve okul yöneticiliğinin en kapsamlı ele alındığı ilk şûra olan 11. MEŞ’te eğitim yöneticiliği bir uzmanlık olarak tanımlanmıştır. Ayrıca eğitim yöneticilerinin görevleri sıralanmış ve nasıl yetiştirileceğine dair kararlar alınmıştır (TTKB, 1982). Bu şûrada alınan kararların bugün de savunulan görüşlerle örtüşmekte olup alınan kararların hayata geçirilmesi için görüş birliği oluştuğu söylenebilir.

Bu şûrada eğitim yöneticisi olmak için yüksek lisans mezunu olma şartı getirilmesi ve bu eğitimin içeriğinin kısmen iş analizine dayalı olarak belirlenmiş olması ve uygulamalı eğitime (staja) yer verilmesi (TTKB, 1982) önemli ve değerli kararlar olarak kabul edilebilir.

12. ve 13. Şûralarda eğitim ve okul yöneticiliği ile ilgili bir karar alınmamıştır (TKK, 1988; 1990).

\section{MEŞ (27-29 Eylül 1993)}

Eğitim yönetimi ve yöneticiliği konusunun milli eğitim sistemimizin öncelikli sorunlarından biri olarak ele alındığı 14. MEŞ’te eğitim yöneticiliğinde uzmanlaşma, yeterlilikler ve eğitim yöneticilerinin yetiştirilmesinin üniversitelerle işbirliği içinde yürütülmesi konuları tartışılmıştır (ТКВ, 1993). 
Bu şûrada alınan dikkat çekici bir karar, yönetici yetiştirme programlarına katılacakların seçilme kriterlerinin belirlenmesi ile ilgili olan maddedir (TKB, 1993). Böylece eğitim yöneticiliğinin öğretmenlikten farklı bir uzmanlık ve kişilik gerektirdiği tespit edilmiş olmaktadır.

\section{MEŞ (13-17 Mayıs 1996)}

Eğitim yöneticiliğine ilişkin geniş tartışmaların ve önemli kararların alındığı bir diğer şûra 15 . MEŞ’tir. Bu şûrada yönetici atamalarında kariyer, liyakat ve başarı kriterlerinin aranması gerektiğ $i$ belirlenmiştir. Ancak bu şûranın en önemli katkısı, eğitim yönetiminin bir bilim olarak kabul edilmesi, yöneticiliğin bir uzmanlık olarak tanımlanması ve meslek olarak kabul edilmesi gerektiğinin karara bağlanmış olmasıdır. Bu şûradaki diğer bir önemli nokta ise yöneticilerin görev, yetki ve sorumluluklarına uygun özlük haklarına kavuşturulması gerektiğinin karara bağlanmış olmasıdır (TKKB, 1996).

15. MEŞ’in diğer bir gündemi olan "Ortaöğretimde Yeniden Yapılanma” başlı̆g altında 1981'deki 10. MEŞ’teki ademimerkeziyetçi beklentilerin pekiştirildiği görülmektedir. Her ne kadar 15 yıl önceki kadar cesur kararlar alınamamışsa da merkeziyetçi yapının tekrar tartışma konusu olması ve yerel yönetimlere yetki devrinin savunulmuş olması kayda değer bir gelişmedir.

\section{6. $M E S ̧$ (22-26 Şubat 1999)}

Mesleki eğitimin gündeme alındığı 16. MEŞ’te de okul ve eğitim yöneticilerinin yeterlilikleri masaya yatırılmıs ve yeterliliklerin geliştirilmesinin gerektiği eylem önerileriyle somutlaştırılmıştır. $\mathrm{Bu}$ şûrada da görevdeki okul yöneticilerinin yeterliliklerinin geliştirilmesi için hizmetiçi eğitim önerisi yüksek lisans eğitimi olarak belirlenmiştir. Ayrıca yöneticilerin mesleki gelişimlerinin planlı ve sürekli olması gerektiği de belirlenmiştir. Bu şûra kararları arasında en dikkat çekici yenilik yöneticilik yeterliliklerinin sertifika eğitimleri ile de geliştirilebilmesinin önünün açılmasıdır. Halihazırdaki lisansüstü eğitime sahip yöneticilerin ve yönetici adaylarının atamada avantajlı hale gelmesini sağlayacak düzenlemelerin yapılması da karara bağlanmıştır (TKKB, 1999).

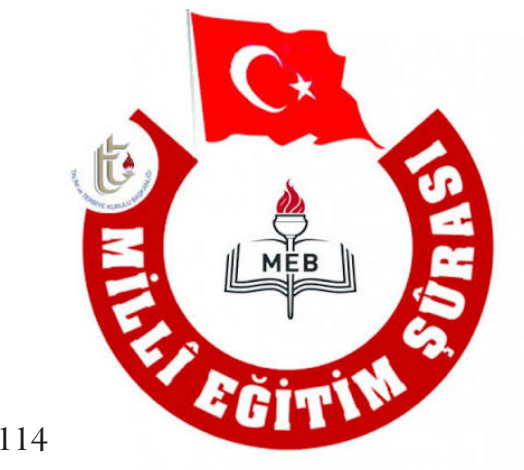

\section{MEŞ (13-17 Kasım 2006)}

Yeni yüzyılın ilk Şûrası olan 17. MEŞ’te teftiş sistemine ilişkin kararlar daha fazla yer almakla beraber eğitim yöneticiliğine ilişkin çok önemli bir karar alınmıştır. İlk 
kez bu şûrada yöneticilik için iş analizine dayalı yöneticilik yeterliliklerinin saptanması kararlaştırılmıştır (TTKB, 2006).

\section{MEŞ (1-5 Kasım 2010)}

Okullaşma oranının hızla yükseldiği iki binli yılların ikinci şûrası olan 18. MEŞ’te eğitim/ okul yöneticileri ile ilgili karar ifadelerinde yeni bilimsel tartışmaların etkilerinin yansıması görülmektedir. Okul kültürü, değerler, kültürel liderlik, işletme, eğitim liderliği, etik liderlik, katılımolik, demokratik liderlik, hesapverebilirlik, vizyoner liderlik, pozitif ayrımollik, bilişim, iletişim, yabancı dil yeterliliği, verimlilik, takım çalışması vb. kavramların kullanılmış olması eğitim yöneticiliği konusunda bir literatürün oluştuğunu göstermesi bakımından önemlidir. Bu şûrada eğitim yöneticilerinin yeterlilikleri, yetiştirilmesi, görevlendirilmesi, hizmet içi eğitimleri konularında alınan kararlar önceki şûralarda da alınan kararlarla benzerlik göstermektedir. Ancak, okul yöneticilerine kendi takımların kurmak amacıyla müdür yardımcılarını seçme hakkı verilmesi, çok kültürlülük yeterlilikleri, beş yılda bir mesleki gelişim amacıyla yeniden eğitime alınmaları gibi öneriler daha önce gündeme gelmemiş kararlardır. Ayrıca bu şûrada 657 sayılı kanunda değişiklik yapılması gerektiğinin karar bağlanmış olması da önemli bir aşamadır (TKB, 2010).

\section{MEŞ (2-6 Aralık 2014)}

Son MEŞ olan 19. Şûra'da okul yöneticiliği kapsamlı biçimde tartışılmış ve oldukça detaylı kararlar alınmıştır. Okul yöneticiliğinin bir uzmanlık alanı olarak kabul edilmesi ve meslekleşmesi yönünde atılan en güçlü adımlardan biri olarak kabul edilebilir. 19. Şûrada okul yöneticiliği konusu, okul yöneticilerinin niteliğinin artırılması ana başlı̆̆ altında okul yöneticisi adaylarının seçilme ölçütleri, okul yöneticiliğine ilk görevlendirme, okul yöneticiliğine yeniden görevlendirme, hizmet içinde yetiştirme ve diğer konular olmak üzere beş alt başlıkta 39 karar alındığı görülmektedir (TKB, 2014).

19. MEŞ kararları, okul yöneticiliği alanında en kapsamlı kararlardır. Kararlar genel olarak okul yöneticiliğinin standarda kavuşması ve meslekleşmesi bakımından birçok yeni kavramı da kapsamaktadır. Eğitim doktorası, lisansüstü eğitimlere göre özlük haklarının iyileştirilmesi mentorluk kurumu, ulusal yeterlik merkezi oluşturulması, eğitim yöneticisi yetiştirme merkezlerinin kurulması, okul yöneticilerinin yetiştirilmesinde akreditasyon sisteminin kurulması, okul karnesi oluşturmak için veri tabanı kurulması, kariyer sisteminin kurulması ve okul yöneticiliğini özendirici yasal düzenlemeler yapılması gibi kavramlar ve benzeri özgün kavramların 19. MEŞ’te kararlara girdiği görülmektedir. 
Aşağıdaki tabloda MEŞ’lerde eğitim ve okul yöneticiliğine dair alınan kararlar maddeler halinde özetlenmiştir.

Tablo 1: MEŞ'lerde Eğitim ve Okul Yönetimi ile İlgili Alınan Kararların Özeti

\begin{tabular}{|c|c|c|c|c|c|c|c|}
\hline $\begin{array}{l}10 . \quad \text { M E Ş } \\
(1981)\end{array}$ & $\begin{array}{l}\text { 11. MESS } \\
\text { (1982) }\end{array}$ & $\begin{array}{l}\text { 14. M E Ş } \\
(1993)\end{array}$ & $\underset{\text { (1996) }}{\text { 15. M E Ş }}$ & 16. MEŞ (1999) & $\begin{array}{l}\text { 17. M E Ş } \\
(2006)\end{array}$ & $\underset{(2010)}{18 .}$ M E Ş & 19. MI \\
\hline $\begin{array}{l}\text { - Hizmet } \\
\text { - } \text { içi eğitim } \\
\text { Eğitim } \\
\text { örgütünde } \\
\text { yetki ve } \\
\text { sorumlulu } \\
\text { k dengesi } \\
\text { - Eğitim } \\
\text { örgütünde } \\
\text { ademimer } \\
\text { keziyetçi } \\
\text { yap1 }\end{array}$ & $\begin{array}{ll}\text { - } & \text { Eğitim } \\
\text { yönetic } \\
\text { isi } \\
\text { tanımı } \\
\text { - Eğitim } \\
\text { yönetic } \\
\text { iliği } \\
\text { için } \\
\text { yüksek } \\
\text { lisans } \\
\text { şartı } \\
\text { Yönetic } \\
\text { ilik } \\
\text { stajı }\end{array}$ & $\begin{array}{l}\text { - Eğitim } \\
\text { yöneticil } \\
\text { iğinde } \\
\text { uzmanla } \\
\text { şma } \\
\text { Yöneticil } \\
\text { erin } \\
\text { yetkileri } \\
\text { nin } \\
\text { arttırılma } \\
\text { s1 } \\
\text { Yöneticil } \\
\text { erin } \\
\text { eğitim } \\
\text { için } \\
\text { seçilmesi } \\
\text { Yönetici } \\
\text { eğitimin } \\
\text { de MEB } \\
\text { üniversit } \\
\text { e iş } \\
\text { birliği }\end{array}$ & $\begin{array}{l}\text { - Kariyer } \\
\text { sistemi ve } \\
\text { liyakat } \\
\text { Eğitim } \\
\text { yöneticiliğ } \\
\text { inin } \\
\text { meslek } \\
\text { olması } \\
\text { Yöneticili } \\
\text { kte } \\
\text { öğretmenl } \\
\text { ik } \\
\text { tecrübesi } \\
\text { Eğitim } \\
\text { yöneticiler } \\
\text { inin } \\
\text { yüksek } \\
\text { lisans } \\
\text { eğitimi ile } \\
\text { yetiştirilm } \\
\text { esi } \\
\text { Okul } \\
\text { yöneticisi } \\
\text { nin yetki } \\
\text { ve } \\
\text { sorumlulu } \\
\text { k dengesi } \\
\text { Yönetimd } \\
\text { e iç ve dış } \\
\text { paydaşları } \\
\text { n katılımı }\end{array}$ & 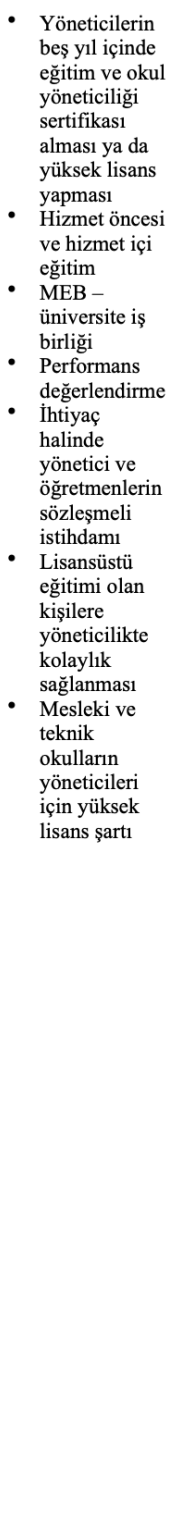 & $\begin{array}{l}\text { - İş } \\
\text { analizine } \\
\text { dayalı } \\
\text { yönetici } \\
\text { yeterlilik } \\
\text { lerinin } \\
\text { saptanm } \\
\text { as1 }\end{array}$ & 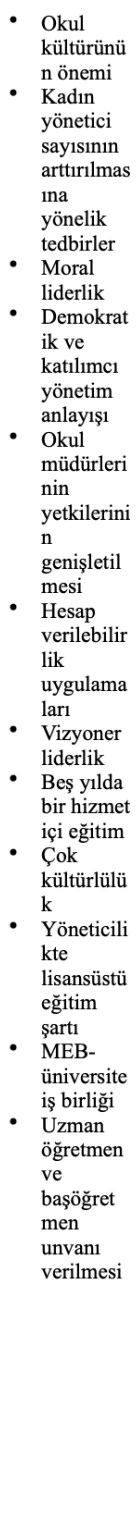 & 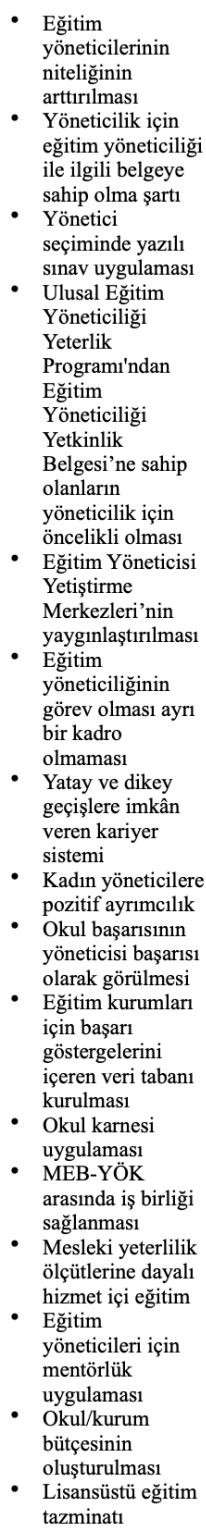 \\
\hline
\end{tabular}




\section{Sonuç}

Milli eğitim sistemimizin en zayıf yönü eğitim yöneticiliği alanıdır. $\mathrm{Bu}$ alandaki zafiyet hem mevzuat hem de yeterlilikler düzeyinde sürekli tartışma konusu olmakta ve işleyen bir sistem oluşturmakta güçlük çekilmektedir. Bu zafiyetin ortadan kaldırılması eğitim politikalarının özüne uygun bir biçimde alanda uygulanabilmesi ivedi bir ihtiyaçtır. Ayrıca öğretmen yeterliliklerinin artırılması, eğitim bütçesinin etkili ve verimli kullanılması, veli katılımı ve değişimin başarılı bir biçimde sürdürülmesinin anahtarı da mesleki bakımdan güçlü eğitim ve okul yöneticileridir.

Eğitimyönetimi ile ilgili 1981 yılında yapılan 10. MEŞ’e kadar eğitim ve okul yöneticiliği ile ilgili belirgin özel bir karar alınmamıştır. 10. MEŞ kararlarında Türk Eğitim Sistemi'nde âdemimerkeziyetçi bir yapıya dönüşmesinin gerekliliklerinden ve eğitim/okul yöneticileri için hizmet içi eğitimlerin öneminden bahsedilmiştir. 1982 yılında düzenlenen 11. MEŞ eğitim yöneticisinin tanımı ve yüksek lisans uygulamalarından bahsedilmiştir. 1993 yllında düzenlenen 14. MEŞ’in gündemi ise eğitim yöneticiliğinde uzmanlaşma ve eğitim yönetiminde denetim konuları üzerinde durulmuştur.

14. Şûra eğitim yönetimi konusunun etraflıca tartışıldığı ilk şûra olma özelliğini taşımaktadır. Okul yöneticilerine yöneticilik becerilerinin kazandırlmasın amaçlayan ve günümüzde de devam eden üniversiteler ve MEB arasinda iş birliği ilkesi ilk kez bu şûrada gündeme gelmiştir. 1996 yılında düzenlenen 15. MEŞ’in gündemi ortaöğretimin yapılandırılması olsa da okul yöneticiliği konularına da değinildiği görülmektedir. 15. MEŞnda görüşülen bazı konular okul yöneticileri için kariyer sistemi ve liyakate dayal görevlendirme, yöneticilikte 
ögretmenlik tecrübesine sahip olmast, eğitim yöneticilerinin yüksek lisans programları ile yetiştirilmesi, yönetsel faaliyetlerde öğretmen, öğrenci ve velilerin aktif rol almalarının sağlanması gibi eğitim yönetimi ile ilgili önemli konular bulunmaktadır. Günümüzde halen okul yöneticilerinin sık sık dile getirdiği "okul yöneticiliğinin meslek olması” ilk kez bu şûrada gündeme gelmiştir.

1999 yılında düzenlenen 16. MEŞ’te gündem maddesi mesleki eğitimde öğretmen ve yönetici yetiştirmedir. Buna göre, o dönemde görev yapan okul yöneticilerinin beş yıl içinde eğitim ve okul yöneticiliği sertifikası alması ya da yüksek lisans yapması, yöneticilere hizmet öncesi ve hizmet içi eğitim verilmesi, okul yöneticilerinin performanslarının değerlendirilmesi, ihtiyaç durumunda sözleşmeli yönetici ya da ögretmen istihdamının yapılması, lisansüstü eğitim alan kişilere yöneticilikte kolaylık sağlanması ve mesleki ve teknik okullarda yöneticilik için lisansüstü eğitim şartının getirilmesi görüşülmüştür. Ayrıca okul yöneticilerine gerekli yetkinliklerin kazandırılmasını sağlayan lisansüstü eğitim çalışmalarının devamlllı̆̆ için MEB ve üniversiteler arasındaki iş birliğine dikkat çekilmiştir.

2006 yllında gerçekleşen 17. MEŞ’te ilk kez iş analizine dayal "yönetici yeterlilikleri" konusu gündeme gelmiştir. 2010 yılındaki 18. MEŞ’te alanyazında eğitim yönetimi ile ilgili artan çalışmalar etkisini göstermiş ve okul kültürü, moral liderlik, katıllmcı yönetim, vizyoner liderlik, hesap verilebilirlik ve çok kültürlülük gibi önemli kavramlara yer verilmiştir. Ayrıca yöneticilerin yaşanan değişime daha kolay adapte olabilmesi için beş yılda bir hizmet içi eğitim almasınn gerektĭgi belirtilmiştir. Yöneticilikte lisansüstü eğitimin gerekli bir unsur 
olması ve yüksek lisans mezunlarına uzman öğretmen, doktora mezunlarına ise başöğretmen unvanı verilmesi önerilmiştir. $M E B$ ve üniversiteler arasındaki iş birliğinin devam etmesine ek olarak ilk kez kadın eğitim yönetici sayısının arttırılması için uygulamalar yapılması gerektiği belirtilmiştir. Bu kapsamda, 2014 yılında MEB Eğitim Kurumlarına Yönetici Görevlendirme Yönetmeliği’nde değişiklikler yapılarak kadın yöneticilere pozitif ayrımcılık yapılmış ve böylelikle sayının arttırılması amaçlanmıştır:

“(5) Öğrencilerinin tamamı kız olan eğitim kurumlarının müdürleri ile bu kurumlar ve yatılı kız öğrencisi bulunan eğitim kurumlarının müdür yardımcılarından en az biri kadın adaylar arasından görevlendirilir.

(6) Karma eğitim yapılan ve müdür yardımcısı sayısı üç ve daha fazla olan eğitim kurumlarının müdür yardımcılarından en az biri kadın adaylar arasından görevlendirilir” (MEB, 2018)

Son olarak, 2014 yılında gerçekleşen 19. MEŞ’te ise eğitim yöneticilerinin niteliğinin arttırılması, yöneticilerin seçiminde yazılı sınav uygulanması, eğitim yöneticiliğinin görev olması, kariyer sisteminin genişletilmesi, kadın yönetici adaylarına pozitif ayrımcılık, okul başarısının yönetici başarılı olarak görülmesi, okul karnesi uygulaması, yöneticilikte mentörlük uygulaması, mesleki yeterlilik ölçütlerine dayalı hizmet içi eğitim, okul bütçelerinin oluşturulması ve lisansüstü eğitim tazminatı gibi konular görüşülmüştür. Bu noktada, 19. Şûra'da görüşülen "Eğitim Yöneticilerinin Niteliğinin Arttırılması” başlığı altında 11 tavsiye kararı bulunmaktadır.

Görüldüğü gibi eğitim ve okul yöneticiliği konusu son 39 yıl içinde gerçekleştirilen 10 Şûrada (10-19. MEŞ’ler) etraflıca tartışılmış hemen hemen bütün konularla ilgili uygulamaya yönelik öneriler karara bağlanmıştır. Bu şûralarda alınan kararları şöyle özetlemek mümkündür:

1. Eğitim/okul yönetiminin bir bilim alanıdır.

2. Eğitim yöneticiliği bir uzmanlık alanıdır ve kariyer mesleği olarak tanımlanmalıdır.

3. Eğitim yöneticiliğinin iş analizine dayalı yeterlilikleri belirlenmelidir.

4. Eğitim yöneticisi adayları yöneticilik potansiyeli olan öğretmenlerden seçilmelidir.

5. Seçilen eğitim yöneticisi adayları lisansüstü sertifika, master ve/veya doktora programına katılmalidir.

6. Eğitim yöneticiliği eğitim programları iş analizine dayalı yeterlilikleri kazandırmaya yönelik olmalıdır.

7. Eğitim yöneticiliği eğitim programları uygulama (staj) ağırlıklı olmalıdır. 
8. Eğitim yöneticileri görev, yetki ve sorumluluklarıyla uyumlu özlük haklarına kavuşturulmalıdır.

9. Görevdeki eğitim yöneticilerinin mesleki gelişimlerini standartlara kavuşturulması için planlı ve sürekli hizmet içi eğitim programları düzenlenmelidir.

10. Eğitim yöneticilerinin eğitimi MEB ile üniversitelerin koordinasyonuyla yürütülmelidir. 11. Eğitim yöneticilerinin seçimi, görevlendirilmesi, yükseltilmesi ya da görevden alınması iş analizine dayalı yeterlilikler çerçevesinde oluşturulacak performans kriterleri ile ve katılımcı bir yaklaşımla şeffaf bir biçimde gerçekleştirilmelidir.

Eğitim yöneticiliği ve okul yöneticiliği 10. Şûraya kadar belirgin bir gündem konusu olmammış ve özel bir karar alınmamıştır. Eğitim yönetimi konusu özellikle 14. MEŞ’te gündeme gelmiştir. 18. ve 19. şûralarda eğitim ve okul yöneticileri ile ilgili pek çok madde görüşülmüştür. Ancak şûra tarafından alınan kararlar sadece bir tavsiye niteliği taşıdığı için kararların birçoğu halen uygulamaya konulmamıştır. MEŞ’lerde eğitim ve okul yönetimi ile ilgili önemli kararlar alınsa da bu kararların uygulanması konusunda sıkıntılar yaşanmaktadır.

\section{Kaynakça/References}

Aydın, A. (1998). Şûra kararlarının demokratiklik ve bilimsellik nitelikleri. Eğitim ve Bilim, 22(107), 4-7.

Bayrak, C., Himmetoğlu, B. \& Ayduğ, D. (2020). Okul yöneticilerinin 19. Milli Eğitim Şurası Kararları ve 29026 sayılı yönetmelik çerçevesinde okul yöneticilerinin atanması ve değerlendirilmesine ilişkin görüşleri. Anadolu Üniversitesi Eğitim Fakültesi Dergisi (AUJEF), 4(2), 122-142.

Cumhurbaşkanlığı, (2018). Anayasada yapılan değişikliklere uyum sağlaması amacıyla bazı kanun ve kanun hükmünde kararnamelerde değişiklik yapılması hakkında 703 sayılı kanun hükmünde kararname. Resmi Gazete. 9 Temmuz 2018, sayı: 30473. https://www.resmigazete.gov.tr/ eskiler/2018/07/20180709M3.htm

Çakır, C. (2017). Geçmişten günümüze Türk eğitim sistemindeki gelişmeler: bir kamu politikası aktörü olarak MEŞ’ler özelinde bir değerlendirme. Sosyal ve Beşerî Bilimler Dergisi, 9(2), 31-48.

Duman, A. (1988). Türk eğitim sisteminde uzman ve uzmanlık sorunu. Eğitim ve Bilim, 12(69), 29-35.

Eriş, S. (2006). 1961-1987 yılları arasında gerçekleştirilen MEŞ’ler ve alınan kararların uygulamaları. Yayımlanmamış Doktora Tezi. Selçuk Üniversitesi Sosyal Bilimler Enstitüsü, Konya.

Gülşen, C. \& Özkan, E. (2016). Türk eğitim sisteminde milli eğitim şuraları. TURANSAM Turan Stratejik Araştırmalar Merkezi Dergisi, 8(32), 543-551.

MEB. (2014). Milli eğitim şuraları yönetmeliği. Resmî Gazete, 08.07.2014, sayı: 29054.

https: //www.mevzuat.gov.tr/mevzuat?MevzuatNo=19846\&MevzuatTur=7\&MevzuatTertip=5 (24.12.20)

MEB. (2018). MEB eğitim kurumları yöneticilerinin görevlendirilmelerine ilişkin yönetmelik. Resmî Gazete, 21.06.2018, sayı: 30455. https://www.mevzuat.gov.tr/mevzuat?MevzuatNo=24694\&MevzuatTur= 7\&MevzuatTertip=5 (24.12.2020) 
Öz, H. (2019). Veri temelli okul yöneticisi seçme, yetiştirme ve görevlendirme modeli. Sosyal Bilimler ve Eğitim Dergisi, 2(2), 311-334.

Serçin, F. (2019). 2008-2018 yılları arasında yapılan MEŞ’lernda eğitim yönetimi ve denetimi alanında alınan kararlar. Yayımlanmamış Yüksek Lisans Tezi. Pamukkale Üniversitesi Eğitim Bilimleri Enstitüsü, Denizli.

Talim ve Terbiye Kurulu Başkanlı̆̆ı [TTKB] (1981). 10. milli eğitim şurası kararları. https://ttkb.meb.gov.tr/ meb_iys_dosyalar/2017_09/29165120_10_sura.pdf

Talim ve Terbiye Kurulu Başkanlığı [TKB] (1982). 11. milli eğitim şurası kararları. https://ttkb.meb.gov.tr/ meb_iys_dosyalar/2017_09/29165200_11_sura.pdf

Talim ve Terbiye Kurulu Başkanlığı [TKK] (1988). 12. milli eğitim şurası kararları. https://ttkb.meb.gov.tr/ meb_iys_dosyalar/2017_09/29165252_12_sura.pdf

Talim ve Terbiye Kurulu Başkanlığı [TTKB] (1990). 13. milli eğitim şurası kararları. https://ttkb.meb.gov.tr/ meb_iys_dosyalar/2017_09/29165326_13_sura.pdf

Talim ve Terbiye Kurulu Başkanlığı [TKKB] (1993). 14. milli eğitim şurası kararları. https://ttkb.meb.gov.tr/ meb_iys_dosyalar/2017_09/29165401_14_sura.pdf

Talim ve Terbiye Kurulu Başkanlığı [TКB] (1996). 15. milli eğitim şurası kararları. https://ttkb.meb.gov.tr/ meb_iys_dosyalar/2017_09/29165430_15_sura.pdf

Talim ve Terbiye Kurulu Başkanlığı [TTKB] (1999). 16. milli eğitim şurası kararları. https://ttkb.meb.gov.tr/ meb_iys_dosyalar/2020_02/21142534_16_sura.pdf

Talim ve Terbiye Kurulu Başkanlığı [TКК] (2006). 17. milli eğitim şurası kararları. https://ttkb.meb.gov.tr/ meb_iys_dosyalar/2017_09/29165619_17_sura.pdf

Talim ve Terbiye Kurulu Başkanlığı [TТКB] (2010). 18. milli eğitim şurası kararları. https://ttkb.meb.gov.tr/ meb_iys_dosyalar/2017_09/29170222_18_sura.pdf

Talim ve Terbiye Kurulu Başkanlığı [TKKB] (2014). 19. milli eğitim şurası kararları. https://ttkb.meb.gov.tr/ meb_iys_dosyalar/2019_12/10095332_19_sura.pdf

TDK. (2020). Türk dil kurumu online sözlük. https://sozluk.gov.tr/

TED. (2014). 19. millî eğitim şûrasına ilişkin değerlendirmeler. Ankara: TEDMEM Güncel Yayınlar.

Üçler, C. (2006).1988-2005 yılları arasında gerçekleştirilen MEŞ’ler ve alınan kararların uygulamaları. Yayımlanmamış Doktora Tezi. Selçuk Üniversitesi Sosyal Bilimler Enstitüsü, Konya.

Ürey, S. \& Yllmaz, M. (2015). Eğitimde denetimde ilkelere uygunluğun değerlendirilmesi. Akademik Sosyal Araştırmalar Dergisi, (3)20, 144-155. 


\section{Ek-10-19 Milli Eğitim Şuralarında Eğitim ve Okul Yönetimi ile İlgili Kararlar \\ 10. $\operatorname{MES}(1981)$}

13- Mevcut okul öncesi eğitim kurumları öğretmen, yönetici ve uzman personelin hizmet içi eğitimden geçirilmesi.

34- Öğretmen, yönetici ve uzmanların hizmet içi eğitimlerinin sağlanması.

\section{7- Eğitim Örgütü}

c) Yetki ve sorumluluğun, merkez ile taşra yönetimi arasında dengeli olarak dağıtılması.

d) İlçe eğitim yönetiminin üstünde il eğitim yönetimi ve MEB yönetim düzeylerinin yer alması.

e) İlçenin, eğitim hizmetinin yürütülmesinde ve eğitim yatırımlarının gerçekleştirilmesinde, etkin bir yönetim birimi hâline getirilmesi.

f) Okulun, eğitim örgütünde temel yönetim düzeyi olarak ele alınması.

\section{1. $\operatorname{MEŞ}(1982)$}

1- Eğitim Yöneticisi

\section{a) Uzmanın Tanımı}

Eğitim yöneticisi; değişik sistem, kurum ve kademelerde eğitim hizmetlerini yönetmeye yeterli olarak nitelikte kuramsal alanda ve uygulamada yetişmiş uzmandır.

\section{b) Görevleri}

1) Eğitim yöneticisi; değişik eğitim kurumlarında, okullarda, eğitim kademelerinde eğitim programlarına; öğrenci hizmetlerine, personel hizmetlerine; bütçe işlerine; eğitim bina, araç ve gereçlerine ilişkin işleri yönetir.

2) Yönettiği kurum, okul veya kademenin eğitim amaçlarını gerçekleştirmek için yönetim süreçlerini etkin biçimde işletir.

3) Yönettiği teşkilatın alt sistemlerinin bir bütün olarak, teşkilatla ilgili amaçları gerçekleştirecek şekilde çalışmasını sağlar.

\section{c) Uzmanın Eğitimi İçin Teklif Edilen Model}

Eğitim yöneticisi olabilmek için yüksek lisans eğitimi gereklidir. Eğitim yönetiminde lisans eğitimi görenler yönetici yardımcısı (uzman yardımcısı) olarak atanmalıdır. Eğitim yöneticisi olacaklar;

1) Lisans düzeyinde, eğitim bilimlerinde, eğitime temel olan diğer bilimlerde ve yönetim bilimlerinde dersler almalidır.

Yönetim bilimlerinde alınacak dersler yönetim bilimi, eğitim yönetimi yönetim hukuku eğitimde teftiş, ögrenci hizmetlerinin yönetimi, personel hizmetlerinin yönetimi gibi dersler almalıdır. Ayrıca, alan çalışmaları ve uygulamalı çalışmalardan oluşan staj programların 
tamamlamış olmalıdır.

2) Yüksek lisans düzeyinde ise, eğitim ve yönetim bilimlerinde uygulamaya ağırlık veren uzmanlık dersleri almalı ve bir tez çalışması yapmalıdır.

\section{4. $\operatorname{MEŞ}(1993)$}

4- Eğitim yöneticiliğinde uzmanlaşma, hiyerarşik ilerleme ve yükselme esas alınacak ve yöneticilerin yetkileri artırilacaktır.

5- Mevcut eğitim yöneticileri, üniversiteler ile iş birliği içinde yetiştirilecek; eğitim yöneticiliği programına, yöneticilerde bulunması gerekli nitelikleri taşıyanlar alınacaktır.

\section{5. $\operatorname{MEŞ~(1996)~}$}

64-Yönetici atamalarında kariyer, liyakat, başarı aranmalı, üst kademeye geçişler başarılar ölçüsünde, belli bir sisteme göre olmalıdır.

71- Eğitim yönetiminin bir bilim olarak algılanması, yöneticinin, örgütsel amaçların gerçekleştirilmesini sağlayan bir eğitim lideri olarak kabul edilmesi, bu alanın uzmanlı gerektirdiğinin bilinmesi, eğitim yöneticiliğinin meslek hâline getirilmesi gerekmektedir.

72- Eğitim yöneticiliği bil fiil öğretmenlik tecrübesine dayanmalıdır.

73- Eğitim yöneticisi lisans üstü eğitimle yetiştirilmeli, yönetici adayları objektif ölçülerle seçilmeli ve özlük hakları, yaptıkları, iş ve eğitim düzeyine göre düzenlenmelidir.

74- Okul yöneticisinin yetki ve sorumluluk dengesi sağlanmalıdır.

75- Belirli alanlarda (il, ilçe, semt) kurulmuş olan eğitim kurumlarının, madde ve insan kaynaklarından tam kapasite ile yararlanabilecekleri bir yönetim sistemi oluşturulmalıdır.

76- Yönetimde gerçek katılım ortamı oluşturularak; öğrenci, öğretmen, veli ile çevrenin katkı ve katılımı sağlanmalıdır.

3- Merkez ve taşra örgütleri yöneticilerinin yetki ve sorumlulukları, toplumun eğitim ihtiyacı da dikkate alınarak yeniden belirlenmeli, bu birimlere yapılacak atamalarda uzmanliğa ve deneyime önem verilmelidir.

4- Taşra örgütüne daha çok yetki ve sorumluluk verilmeli, karar oluşumuna eğitimcilerin, taşra yöneticileri ve halkın katılımı sağlanmalıdır.

\section{6. $\operatorname{MEŞ}(1999)$}

1.Çalışan yöneticilerin üniversitelerle iş birliği yapılarak en çok 5 yıl içerisinde ve bir proje kapsamında eğitim ve okul yöneticiliği sertifikası ve bunu izleyen lisans üstü programlarına katılmaları sağlanmalıdır. Bu amaçla eğitim ve okul yöneticileri sertifika programlarında alınan krediler yüksek lisans mezunu yöneticilerin de lisans 
tamamlama programlarına alınarak aynı imkânlardan yararlanmaları sağlanmalıdır.

2.Yöneticilerin hizmet öncesi v hizmet içi eğitimleri üniversiteler ve diğer kuruluşlarla da iş birliği yapılarak planlı ve sürekli hâle getirilmelidir.

3.Öğretmen ve yöneticilerin performans değerlendirme ölçütleri geliştirilmeli, mevcut sicil raporları bu ölçütlerine göre düzenlenmeli ve şeffaf olmalıdır.

4.Öğretmen ve yöneticiler yerel düzeyde okul bazında ve gereksinim olması hâlinde sözleşmeli olarak istihdam edilmelidir.

5.Hizmet içi eğitim ihtiyaçları uygun yöntem ve tekniklerle belirlenmeli, eğitime katılacak yönetici, eğitimci ve eğitilecekler bu ihtiyaçlar dikkate alınarak seçilmelidir.

6.Eğitim yönetimi ve kamu yönetimi alanlarında yüksek lisans eğitimi yana öğretmenlere okul yöneticiliğine atanmada sağlanan kolaylik, diğer yöneticilik alanlarında yüksek lisans yapanları da kapsamalıdır. Mesleki ve teknik eğitim okullarına yönetici atamalarında eğitim yöneticiliği alanında lisans veya yüksek lisans zorunluluğu getirilmelidir.

\section{7. $\operatorname{MES}$ (2006)}

1.Yönetim kademelerine göre iş analizine dayalı "yönetici yeterlikleri” saptanmalıdır.

\section{8. $\operatorname{MEŞ}(2010)$}

1. Kurumsallaşma, bir kurumun ortak kültürünün oluşması süreci olup bu konuda en önemli etmenlerden biri de okul yöneticileridir. Bu nedenle okulda güven, karşılıkl saygı, sevgi, hoşgörü, başarı gibi değerlere dayah okul kültürünün oluşmasında liderlik rolünü üstlenebileceklerin yönetici olarak atanmaları hususunda gerekli düzenlemeler yapılmalıdır 2.Okullarda kültürel yönden ortak kültür çevresinde bütünleşmenin sağlanması için okul müdürlerinin kültürel liderlikle ilgili yeterliliklere sahip olmaları sağlanmalıdır.

3.Güçlü okul kültürlerinin oluşturulup sürdürülebilmesi için okullarda öğretmen ve yöneticilerin uzun süreli istihdamını sağlamaya dönük tedbirler alınmalıdır.

4.Okul müdürlerinin eğitim- öğretim liderliği ve işletme yöneticiliği rolleri birbirinden ayr düşünülmeli, okul yöneticileri genel idari hizmetler sinıfina alınmal, yeni kadro ihdası yapılmalıdır. Okul müdürlerinin seçimi ve istihdamında portfolyo, süreç değerlendirme vb. alternatif seçme yöntemleri esas alınarak geliştirilecek mesleki yeterlilikler dikkate alınmal, okulların idari ve akademik örgütlenmesi yeniden tasarlanmalı ve bu amaçla 657 sayıl Devlet Memurları Kanunu'nda değişiklik yapılmalıdır.

$5 . O k u l$ yöneticiliğine atamada kadın yöneticilerin sayısını arttırmaya dönük teşvikler sağlanmalı; okulların özellikleri dikkate alınarak müdür yardımcılı̆ğ 
ve rehber ögretmen atamalarında kadınlar için norm kadro tahsis edilmeli, sınıf rehber ögretmenlerine rehberlik eğitimi sağlanmalıdır.

$6.0 k u l$ yöneticilerinin, moral lider olarak söz ve davranıslarıyla okul toplumunun üyeleri için bir davranış ve rol modeli olmaları sağlanmal, okul müdürleri etik liderlik davranışları sergilemelidir.

7.Okulda katılımo ve demokratik bir yönetim anlayışı geliştirilmeli, okul yönetiminde kurulların daha etkin hâle gelmesi sağlanmalıdır.

$8.0 \mathrm{kul}$ yönetimiyle ilgili mevzuat sadeleştirilerek yöneticilerin, liderlik davranışı sergileyebilmeleri için başta müdür yardımcılarını atayabilme yetkileri olmak üzere, inisiyatif alanları genişletilmeli, yetki ve sorumlulukları yeniden belirlenmelidir.

9.Hesap verilebilir bir okul anlayışı geliştirebilmek için yöneticiler, okul yönetimi ve performansıyla ilgili geliştirilecek nesnel ölçütlere dayalı olarak değerlendirilmeli, buna bağh olarak ödül, teşvik ve yaptırım sistemi geliştirilmelidir.

10.0 kul yöneticilerinin maaş karşılı̆ı ders saatleri yeniden düzenlenmeli, yöneticilerin aldikları ek ders ücretleri arasındaki adaletsizlik giderilmeli, derse girme mecburiyeti kaldırılmalı veya 6 saat derse girme zorunluluğu "6 saate kadar derse girer." şeklinde değiştirilmelidir.

11. Okuldaki yönetici ve öğretmenler dışındaki eğitim çalışanlarının tayin ve terfileri nesnel ölçütlerle belirlenmeli, eğitim-öğretim ödeneği verilebilmesi için gerekli düzenlemeler yapılmalıdır.

12.Okul yöneticilerinin, atanacakları bölge ve okullarla ilgili vizyoner liderlik özelliklerine sahip olmaları bir ölçüt olarak değerlendirilmelidir.

13.Okul lideri yetiştirme ve istihdamında, Türkiyénin bölgesel koşulları göz önünde bulundurularak okul liderlerine zor koşullarda görev yapacak ve sorumluluk alacak yeterlilikler kazandırılmalıdır.

14. Bölgesel ve yerel özellikler dikkate almarak başta dezavantajl bölgeler olmak üzere yönetici atamalarında pozitif ayrımcılı̆g dayalı özendirici önlemler alınmalıdır.

15. Okul yöneticileri yeterliliklerinin geliştirilmesi için, beş yılda bir yönetim, bilişim, iletişim, liderlik, toplantı vezamanyönetimi vb. konulardan hizmetiçieğitim seminerlerine alınmalıdır. Program ve eğitimler, uygulamaya dönük ve sorun çözmeye odakh tasarlanmalıdır.

16.Eğitimyöneticilerinin, farkhı toplumvekültürleritanımaları, çok kültürlüortamlardagörev yapacak şekilde yetiştirilmeleri ve yabancı dil becerilerini geliştirmeleri sağlanmalıdır.

1.Eğitim çalışanlarına branşında rehberlik ve teftiş esas alınmal, eğitim müfettişleri kendiaralarındauzmanlaşmışekiplere ayrılmalı, işdisipliniveverimlilikgereğieğitim müfettiş yardımcısı, eğitim müfettişi, eğitim başmüfettişi şeklinde kariyerlendirilmeli, her yıl yerine üç yılda bir teftiş esas alınmalıdır. 
1.Okullarda çalışan rehber öğretmen/psikolojik danısmanlar ile rehberlik ve araştırma merkezlerinde çalı̧̧an personel, alandan mezun müfettişler tarafindan denetlenmeli, bu amaçla müfettişlik alanında uzmanlaşma sağlanmalıdır.

1. Okul yöneticilerinin atamasında, lisansüstü eğitim görme esas alınmal, mevcut yönetici ve öğretmenlerin kişisel gelişimleri açısından üniversiteler ile MEB arasında gerekli koordinasyonla uzaktan veya örgün eğitim yoluyla yüksek lisans ve doktora eğitimi almaları sağlanmal, bu bağlamda verilecek izinler yasal bir düzenlemeyle güvence altına alınmal,, bu ögretmenlerin maaşlarında belirli oranda artış sağlanmalı, yüksek lisans derecesine sahip olanlara uzman öğretmenlik, doktora derecesine sahip olanlara başöğretmenlik unvanı verilmelidir.

\section{9. $\operatorname{MEŞ}(2014)$}

\section{Kararlar:}

\section{Eğitim Yöneticilerinin Niteliğinin Artırılması}

Önerilerin hangi yönetim kademelerini kapsadığına ilişkin yapılan tartışmaların sonrasında eğitim yöneticisi, okul yöneticisi kavramının tanımlanması gerektiği kararı alınmıştır. $\mathrm{Bu}$ bağlamda, eğitim yöneticisi denildiğinde eğitim kurumu yöneticiliğinden ilçe, il ve Bakanlık yönetim kademelerinin; okul yöneticiliği denildiğinde ise okul müdürü ve müdür yardımcılarının anlaşılması gerektiği kararlaştıılmıştır.

Eğitim yöneticilerinin niteliğinin artırılması gündem konusu ile ilgili olarak Genel Kurul aşağıdaki tavsiye kararlarını almıştır:

\section{Eğitim Yöneticisi Adaylarının Seçilme Ölçütleri}

1.1. Devlet okullarında eğitim yöneticisi olmak için lisans derecesine sahip olunması.

1.2. Okul yöneticilerinin merkezi olarak yapılan yazıl sınavda başarılı olması.

1.3. Okul müdürlerinin, belirli bir süre görev yapmış müdür yardımcıları arasından seçilmesi. 1.4. Okul yöneticiliğine atanmada o okula öğretmen olarak atanma şartların taşıma esastır. Ancak atanma şartların taşımadan; o okula münhasıran norm durumu değil genel anlamda o okul türüne atanabilme şartı aranmasının yeterli görülmesi.

1.5. Farklı okul türlerine göre yapılacak yönetici görevlendirmelerinde okul türüne uygun branşlardan yönetici görevlendirilmesine özen gösterilmesi.

1.6. "Okul yöneticiliğine atanmada eğitim yönetimi alanında lisansüstü eğitim almış olma ile okul müdürlüğ̈̈ için yönetici yeterliklerini esas alan, akredite edilmiş kurumlar tarafindan verilebilen belli sürede eğitim alındığını gösterir belgeye sahip olma” şartlarının okul yöneticisi seçiminde tercih nedeni olmasi.

1.7. Yöneticilerin seçiminde, ulusal düzeyde yapılandırılmış Ulusal Eğitim Yöneticiliği 
Yeterlik Programı'ndan Eğitim Yöneticiliği Yetkinlik Belgesi almış olmasının tercih sebebi olmasi.

1.8. Okul yöneticisinin görevlendirilmesinin Okul Müdürü Görevlendirme Mülakat Komisyonu tarafından yürütülmesi; daha üst düzeydeki yönetici atamalarında da bu komisyona benzer komisyonlar oluşturulması

1.9. Okul Müdürü Görevlendirme Mülakat Komisyonunun il millî eğitim müdürü veya görevlendireceği il millî eğitim müdür yardımcısının başkanlı̆̆ında, ilçe millî eğitim müdürü, şube müdürü ve mevcut müdürler tarafından seçilmiş birer temsilciden oluşturulması.

1.10. Yönetici adaylarının yetiştirme programlarına erişimini kolaylaştırmak, yerel imkânlardan faydalanmak ve çok sayıda adaya ulaşabilmek amacıyla yönetici yetiştiren Eğitim Yöneticisi Yetiştirme Merkezleri’nin (EYYM) İstanbul ve Ankara'dan başlanarak ülke geneline yaygınlaştırılması için Bakanlı̆̆ın çalışma başlatması; bu yaygınlaştırmada TÜİK tarafindan tanımlanmış bölge tanımlamasının (12 bölge) esas alınmast.

\section{Eğitim Yöneticiliğine İlk Görevlendirme}

2.1. Okul/kurum yöneticiliğinin "görev" olarak görülmesi ve belli bir süre ile sinırlandırılması.

2.2. Eğitim yöneticiliğinin ilk basamağı olan müdür yardımcılı̆g konumlarına yapılacak görevlendirmelerde okul müdürünün takdirinin öncelikli olması.

2.3. Okul/kurum müdür yardımcısının, en az 3 yıl görev yapmış ve merkezi sınavda başarılı olmuş ögretmenler arasından müdürün teklifi ve üst makamın onayı ile görevlendirilmesi.

2.4. Yönetici görevlendirmelerinin eğitim öğretim yılı başlamadan önce tamamlanması.

2.5. Okul/kurum yöneticiliği için kurs/sertifika programlarının kazandırdığı yeterliklerin tespitini ve güvencesini sağlayacak bir akreditasyon sisteminin kurulması.

2.6. Yöneticilikte kariyer basamakları düzenlenmesi ve uygulanması; belirli sürelerde ögretmenlik yapanların önce müdür yardımcılığına, müdür yardımcılĭgı yapanların müdürlüğe, müdürlük yapanların da şube müdürlüğüne atanmayı sağlayacak şekilde kariyer sistemi kurulması, eğitim kurumları müdürlerinin atanmasında ön koşul olarak, en az 2 yıl süre ile müdür yardımcısı olarak görev yapmış olma şartı aranması.

2.7. Bölgesel ve yerel özellikler dikkate alınarak başta dezavantajl bölgeler olmak üzere yönetici atamalarında pozitif ayrımcılığa dayalı özendirici önlemler alınması; bu bölgeler için tecrübeli, akademik donanıma sahip okul yöneticilerinin görevlendirilmesi.

2.8. Ill ve ilçe yöneticilerinin atanmasında eğitim kurumlarında yöneticilik/müfettişlik yapmıs olma şartının aranması.

2.9. Büyükşehir statüsünde olan illere, il millî eğitim müdürü atamalarında eğitim yönetimi alanında lisansüstü eğitim, merkez teşkilatında üst düzey yöneticilik veya il millî eğitim müdürlüğ̈̈ yapmış olma şartlarından birinin aranması. 
2.10. Birinci kademe yöneticilerin seçiminde aranan ölçütlerin benzeri orta ve üst kademe yöneticilerin seçimi için de geliştirilmesi.

2.11. Eğitim kurumları yöneticiliği, il ve ilçe yöneticiliği, eğitim uzmanlı̆̆ı, millî eğitim uzmanlığı, merkez ve taşra teşkilatı şef, şube müdürlükleri ile daire başkanlıkları arasında yeterlikler çerçevesinde yatay ve dikey geçişlere imkân veren adil bir kariyer sistemi kurulmasi.

2.12. Yönetici pozisyonlarına atamalarda kadın yönetici lehine pozitif ayrımcılık getirilmesi.

2.13. Okul ve kurum türlerinden kaynaklanan kadın yönetici lehine pozitif ayrımcılik uygulamasının tüm okullara genişletilerek uygulanması.

\section{Eğitim Yöneticiliğine Yeniden Görevlendirme}

3.1. Eğitim yöneticiliğine yeniden atanmada nesnel, ölçülebilir, ayırt edici ölçütlerin esas alınmast.

3.2. Bir yöneticiyi değerlendirmek için değerlendirme komisyonunda bulunanların, en az bir yıl değerlendirilecek yönetici ile çalışmıs olması.

3.3. Eğitim yöneticilerinin değerlendirilmesinde algı ölçümlerinin yanında, eğitim yöneticisinin görev süresince görev yaptığı okulun temel başarı göstergelerindeki değiş̧imin de dikkate alınmasi.

3.4. Her derece ve türdeki eğitim kurumu için başarı göstergeleri belirlenmeli ve bu göstergelerin eğitim bölgesi, il ve ilçe düzeyinde zamana bağh değişimini gösteren karşılaştırmalı bir veri tabanının oluşturulması.

3.5. Veri tabanı oluşturulurken, performansa olumsuz etkisi olan ve yöneticinin inisiyatif dışında gelişen olumsuzlukların değerlendirmede dikkate alınması.

3.6. Okullar için her yıl somut performans ölçütlerine dayalı bir okul karnesi oluşturulması.

3.7. Politika oluşturma konumunda olan MEB üst düzey yönetim kademelerine, eğitim ve eğitim yöneticiliği alanında deneyimi olan yöneticilerin atanması.

3.8. MEB-YÖK arasinda yapılacak bir protokolle MEB personelinin yüksek lisans ve eğitim doktorası eğitimi almalarının sağlanması, bu bağlamda eğitime erişimin kolaylaştırılması amacıyla yasal düzenlemeler yapılması.

\section{Hizmet İçinde Yetiştirme}

4.1. Hizmet içi eğitim programlarının, mesleki yeterlikler ölçütlerine dayandırılması.

4.2. Hizmet içi eğitim programlarındaki her bir kurs/seminerin belli bir yeterliği kazandırma ve belgelendirme temeline dayalı olması.

4.3. Hizmet içi eğitim programlarının, belli bir probleme çözüm üretmeye yönelik somut çıktıları olan etkinlik ve eylem araştırması temelli yeterlik kazandıran programlar olmasi. 
4.4. Hizmet içi eğitim programlarında görev alacak eğitim görevlilerinin, programın amaç ve içeriğine uygun yeterliğe sahip olması.

4.5. Hizmet içi eğitim programlarında eğitim görevlilerinin dolaşımı esas alınarak eğitimlerin mahallinde düzenlenmesine öncelik verilmesi.

4.6. Hizmet içi eğitim programlar akredite edilerek eğitim yöneticilerinin belli bir zaman diliminde belirli kredide eğitim almalarının sağlanması, giderlerinin kurumca karşılanması ve alınan eğitim, yöneticilerin değerlendirmesinde kullanılması.

4.7. Eğitim yöneticilerinin mesleki gelişimlerinin sağlanmasında kılavuzluk (mentorlük) mekanizmalarının oluşturulması.

4.8. Eğitim yönetimi alanında eğitim almış, deneyim ve başarıya sahip yöneticiler ile maarif müfettişlerinden kılavuz (mentor) olarak yararlanilması.

\section{Diğer Konular}

5.1. Genel bütçeden pay ayrılarak okul/kurum bütçesinin oluşturulması, okul/kurum yönetimince bunun etkili kullanımın sağlayacak bütün gelir ve harcamaların yasal güvence altına alınmasi.

5.2. Lisansüstü programlarda okul kademelerine özgü programların açılması (örnek, özel eğitimin yönetimi, mesleki teknik eğitimin yönetimi, ilköğretim yönetimi, ortaöğretim yönetimi, yükseköğretimin yönetimi gibi), tezsiz yüksek lisans programinda olduğu gibi uygulayııılara yönelik olarak eğitim doktorası programı açılması.

5.3. Döner sermayesi olan okullarda müdür yardımcılarından birisinin işletme/muhasebe alanında formasyona sahip ögretmenler arasından seçilmesine öncelik verilmesi.

5.4. Yöneticinin ders denetimi ve rehberlik görevini etkili bir şekilde yapabilmesi için rehberlik ve denetim modelleri ile yaklaşımları konusunda yeterliklerinin artırılması.

5.5. Lisansüstü eğitim yapan yöneticilerin bu eğitimlerinin karşıliğının, lisansüstü eğitim tazminatı olarak özlük haklarına yansıtılması.

5.6. Millî eğitim uzmanliklarına seçme ve atama sürecinin, ağırlik öğretmenler lehine olacak şekilde değiştirilmesi; millî eğitim uzmanlıklarına ve maarif müfettişliğine geçişte öğretmenler yönünden yaş şartının kaldırılması.

5.7. Maarif müfettişleri arasındaki özlük hakları ve maaş farklılıklarının giderilmesi.

5.8. MEB bütçesinden okullara öğrencibaşına 120 TL ödenek ayrılması için yasal düzenleme yapilmast. 


\section{Ben Okul Müdürüyüm!}

Bir okyanustayım;

Bambaşka hayalleri ve beklentileri olan öğrencilerimin içinde.

Farklı ilgileri, merakları ve yetenekleri kucaklıyorum.

Sayısız tecrübe ve beceriye sahip öğretmenimle yelken açıyorum maviliklere.

Bambaşka kültürler, inançlar ve değerler güç veren rüzgâr yelkenimize.

Ben cesaretle ve güvenle yol alıyorum. 